\title{
Деякі ревматологічні показники у хворих із діабет-асоційованими остеоартритами
}

\section{В.Л. Орленко ${ }^{1}$, К.М. Тронько', O.T. Єлізарова²}

1 ДУ «Інститут ендокринології та обміну речовин ім. В.П. Комісаренка НАМН України»

${ }^{2}$ ДУ «Інститут громадського здоров'я ім. О.М. Марзєєва НАМН України»

\begin{abstract}
Резюме. Наразі актуальною є проблема асоціації поширених ревматичних захворювань, таких як ревматоїднй артрит, остеоартроз та остеопороз із цукровим діабетом (ЦД). До теперішнього часу немає єдиного погляду на роль біохімічних та імунних чинників, які викликають ураження суглобів в умовах коморбідності. Метою даного дослідження була оцінка біохімічних ревматологічних показників у хворих на ЦД 1-го та 2-го типів із діабет-асоційованими остеоартритами. Матеріал і методи. У дослідженні взяли участь 105 пацієнтів, яких розподілили на групи за типом діабету, наявністю та ступенем діабетичної артропатії. Пацієнтам проводили діагностику артропатій за допомогою УзД суглобів і ревмапроби імунотурбодиметричним методом. Результати. У групі пацієнтів із ЦД 1-го типу артропатію виявлено в 64,4\% випадків, у групі із ЦД 2-го типу — у 80,0\% ( $t=1,8 ; p=0,07)$. У хворих з артропатіями виявлено прямий кореляційний зв'язок стадії артропатії з чинниками «антистрептолізин» $(r=0,33 ; p<0,01)$, «ревматоїдний чинник» $(r=0,26 ; p<0,05)$ i «С-реактивний білок» ( $r=0,43 ; p<0,001)$. Встановлено підвищення середнього рівня сечової кислоти зі збільшенням стадії артропатії як у групі з ЦД 1-го типу ( $F=4,4 ; p=0,009)$, так і в пацієнтів із ЦД 2-го типу ( $F=17,9 ; p<0,001)$. Висновок. Отримані результати продемонстрували, що як найбільш чутливі діагностичні критерії у хворих із діабет-асоційованими остеоартритами можна рекомендувати використовувати рівень сечової кислоти в крові, ревматоїдного чинника та С-реактивного білка.
\end{abstract}

Ключові слова: цукровий діабет, діабет-асоційований остеоартрит, ревматологічні показники, сечова кислота.

Наразі відомо, що ревматичні захворювання можуть часто супроводжуватися цукровим діабетом (ЦД) як 1-го (ЦД1), так і 2-го типу (ЦД2). У низці досліджень показано, що ревматоїдний артрит (РА) асоціюється з підвище-

\footnotetext{
* Адреса для листування (Correspondence): ДУ «Інститут ендокринології та обміну речовин ім. В.П. Комісаренка НАМН України», вул. Вишгородська, 69, м. Київ, 04114 Україна. E-mail:zdovado@ukr.net
}

(с) В.Л. Орленко, К.М. Тронько, О.Т. Єлізарова ною захворюваністю та поширеністю ЦД [1, 2]. Крім того, ризик наявності недіагностованого ЦД підвищено в пацієнтів із РА, надто в пацієнтів із тривалим перебігом захворювання [3]. Автоімунна природа РА та ЦД1 обумовлює їх патогенетичну спільність і часту коморбідність. 3 іншого боку, ЦД2, який характеризується розвитком неспецифічного запалення на тлі таких 
чинників, як ожиріння, атеросклероз, артеріальна гіпертензія, має спільне метаболічне підгрунтя для ураження суглобів в умах підвищеного рівня глюкози в крові $[4,5]$. Дослідження останніх років показали, що є ціла низка генів, які пов’язують із підвищеною схильністю як до ЦД1, так і до PA: PTPN22, TNFAIP3, CTLA4 [6]. Деякі препарати, які використовуються в тривалому лікуванні РА, - глюкокортикостероїди та цитостатики - можуть підвищувати ризик розвитку ЦД [7].

Розвиток суглобових проявів РА та ЦД призводить до дисбалансу цитокінів, порушення механізмів адаптивного та вродженого імунітету. Основною ланкою патогенезу $є$ імунна дизрегуляція, що супроводжується автоімунізацією та формуванням різних класів антитіл, а також гіперпродукцією прозапальних цитокінів, хемокінів, молекул адгезії, чинників росту, металопротеїназ, які беруть участь в ураженні тканин суглобів і цілої низки внутрішніх органів, у тому числі підшлункової залози. РА збільшує ризик розвитку ЦД приблизно на 50\%. А ЦД підвищує ризик розвитку артриту, у тому числі РА та пов'язаних із ним захворювань приблизно на 20\% [8, 9]. Майже половина дорослих американців, які хворіють на ЦД, також мають захворювання суглобів. Результати численних досліджень свідчать, що наявність синовіїту, який візуалізується за допомогою артроскопії, магнітнорезонансної томографії (МРТ) або ультразвукового дослідження (УЗД), може виступати маркером коморбідності, тяжкості перебігу PA та ЦД і пов'язаний із ризиком прогресування захворювання [10]. Системне підвищення рівня C-реактивного білка з високою чутливістю відображає запалення синовіальної оболонки в пацієнтів з артритами та пов'язано з рівнем больового синдрому [11]. Відзначимо, що синовіальне запалення в хворих на ЦД досить часто трапляється й асоціюється з рівнем болю та дисфункції суглобів.

Вивчення патогенезу РА дозволило виявити численні функції прозапальних цитокінів, що не стосуються безпосередньо РА, - наприклад, здатність втручатися в різні етапи метаболізму глюкози. Показано, що чинник некрозу пухлин $\alpha$ (TNF- $\alpha)$ та інтерлейкін-6 (IL-6) порушують синтез і роботу інсулінових рецепторів і внутрішньоклітинного транспор- тера глюкози в м'язах, жировій тканині, печінці, поряд із ІЛ1 $\beta$ пригнічують секрецію інсуліну, викликають апоптоз $\beta$-клітин острівців Лангерганса підшлункової залози [12]. Деякі вчені вважають, що РА можна розглядати як модель для вивчення порушень вуглеводного обміну [13]. У кількох дослідженнях у хворих РА продемонстровано зниження рівня функціональних можливостей $\beta$-клітин і наростання інсулінорезистентності периферичних тканин [14]. Взаємним потенціюванням запалення та дисбалансу метаболізму глюкози намагаються пояснити той факт, що поєднання двох захворювань (РА та ЦД) більшою мірою, ніж ізольовані РА або ЦД, збільшує ризик розвитку ішемічної хвороби серця, інфаркту міокарда, інсульту, серцевої недостатності, хронічної хвороби нирок, дисліпідемії, виразок нижніх кінцівок, ретинопатії й ураження периферичних артерій [15].

3 огляду на те, що єдиним енергетичним субстратом для хондроцитів з урахуванням їх виключно анаеробного характеру метаболізму є глюкоза, порушення синтетичних процесів у хрящовій, кістковій і сполучній тканинах на тлі ЦД є досить частим. Гіперглікемія через активацію поліолового шляху метаболізму глюкози та неферментативного глікування білків може призводити до ураження м'язів і періартрикулярних тканин [16].

На тлі ЦД трапляються специфічні ревматичні синдроми типу діабетичної артропатії кисті, нейроостеоартропатії, діабетичної аміотрофії, які не отримали детальної ревматологічної оцінки [17]. За цих синдромів не описано рентгенологічну характеристику уражень кистей і стоп, не дано оцінки імунних порушень, а також не визначено залежність їх від типу ЦД і характеру уражень суглобів. Актуальною залишається проблема асоціації поширених ревматичних захворювань, таких як РА, остеоартроз та остеопороз, із ЦД. Дане питання наразі практично не вивчено. Водночас вивчення даних взаємообтяжуючих асоційованих патологічних станів є необхідним для розробки схем раціональної терапії хворих, які потерпають від поєднаної патології.

Метою даного дослідження була оцінка біохімічних ревматологічних показників у хворих на ЦД1 і 2 із діабет-асоційованими остеоартритами. 
Оригінальні дослідження

\section{Матеріал і методи}

У дослідженні взяли участь 105 пацієнтів, які перебували на лікуванні в ДУ «Інститут ендокринології та обміну речовин ім. В.П. Комісаренка НАМН України». Із них 45 пацієнтів із ЦД1 (14 чоловіків і 31 жінка), та 60 хворих на ЦД2 (19 чоловіків і 41 жінка). За статевим складом групи пацієнтів із ЦД1 і ЦД2 не різнилися $(\mathrm{p}>0,9)$, але в кожній групі достовірно переважали жінки $(\mathrm{p}<0,001)$.

У таблиці 1 наведено характеристики вибірки за віком та тривалістю перебігу ЦД. Середні показники віку пацієнтів та індексу маси тіла (IMT) виявилися очікувано значуще нижчими, ніж хворих на ЦД2 $(\mathrm{p}<0,001)$. Тривалість перебігу ЦД була значно нижчою в групі пацієнтів із ЦД2 ( $>>0,001)$. Відмінностей за статевим складом не виявлено $(\mathrm{p}>0,4)$.

Серед 105 обстежених артропатію виявлено в $77(26,7 \%)$, у решти 28 (73,3\%) хворих дане ускладнення не діагностувалось.

До комплексу обстежень входили традиційні клінічні біохімічні тести. Ревмапроби визначали імунотурбодиметричним методом. Дослідження проводили на біохімічному аналізаторі Human (Німеччина) з використанням діагностичних тест-систем Lachema (Чехія), ліцензованих в Україні. Рівень сечової кислоти (СК) визначали в плазмі крові 3 використанням реактивів BioSystem (Iспанія). Нормальними рівнями СК вважали 210420 мкмоль/л у чоловіків і 150-350 мкмоль/л у жінок. Ступінь компенсації вуглеводного обміну обстежених оцінювали за рівнем глікованого гемоглобіну (HbA1c), який визначали калориметричним методом із тіобар-

таблиця 1. Характеристика обстежених хворих

\begin{tabular}{llllllll}
\hline Група & $\mathbf{n}(\%)$ & \multicolumn{3}{l}{ Вік } & \multicolumn{4}{c}{ Тривалість ЦД } \\
\cline { 3 - 8 } & & $\mathbf{M}$ & $\boldsymbol{\sigma}$ & $\mathbf{m}$ & $\mathbf{M}$ & $\boldsymbol{\sigma}$ & $\mathbf{m}$ \\
\hline ЦД1 & 45 & 37,7 & 8,5 & 1,3 & 21,1 & 8,9 & 1,3 \\
Чоловіки & $14(31,1)$ & 39,3 & 8,7 & 2,3 & 20,6 & 9,2 & 2,5 \\
Жінки & $33(68,9)$ & 36,9 & 8,5 & 1,5 & 21,4 & 8,9 & 1,6 \\
ЦД2 & 60 & 61,3 & 7,7 & 1,0 & 13,1 & 7,2 & 0,9 \\
Чоловіки & $19(31,7)$ & 61,3 & 7,4 & 1,7 & 12,9 & 8,3 & 1,9 \\
Жінки & $41(68,3)$ & 61,3 & 8,0 & 1,2 & 13,2 & 6,8 & 1,1 \\
Обидві групи & 105 & 51,2 & 14,2 & 1,4 & 16,6 & 8,9 & 0,9 \\
Статистика & & & & & & & \\
тип ЦД & & $\mathrm{t}=14,6 ; \mathrm{p}=0,001$ & $\mathrm{t}=4,9 ; \mathrm{p}=0,001$ \\
чоловіки/жінки ЦД1 & $\mathrm{t}=0,8 ; \mathrm{p}=0,405$ & $\mathrm{t}=0,2 ; \mathrm{p}=0,810$ \\
чоловіки/жінки ЦД2 & $\mathrm{t}=0,04 ; \mathrm{p}=0,970$ & $\mathrm{t}=0,2 ; \mathrm{p}=0,873$ \\
\hline
\end{tabular}

бітуровою кислотою. Компенсацію ЦД реєстрували за рівнем НbА1с до 7\%. Наявність і ступінь діабетичної артропатії оцінювали за даними УЗД суглобів, за методикою та класифікацією A. Rosenbloom (1982).

Статистичну обробку отриманих даних проводили за допомогою методів варіаційної статистики стандартного пакета для статистичних підрахунків Statistica 5.0 Microsoft OffiseExel 2003. У праці наведено статистичні показники середніх величин (М), середнє квадратичне відхилення ( $\sigma)$, стандартна помилка середньої величини (m). Для порівняння середніх абсолютних величин у різних групах застосовували t-критерій Стьюдента. Різницю в отриманих результатах вважали достовірною за $\mathrm{p} \leq 0,05$. Для аналізу даних також використано кореляційний, дисперсійний однофакторний, множинний регресійний аналізи, а також дискримінантну статистику.

\section{Результати та обговорення}

У таблиці 2 наведено розподіл пацієнтів за типом ЦД, статтю та наявністю артропатії. У групі пацієнтів із ЦД1 артропатію виявлено в $64,4 \pm 7,1 \%$ випадків, серед пацієнтів із ЦД2 у $80,0 \pm 5,2 \%(\mathrm{t}=1,8 ; \mathrm{p}=0,07)$. За результатами дисперсійного аналізу встановлено, що чоловіки та жінки мають однакові шанси на розвиток артропатії в обох групах $(\mathrm{p}>0,5)$.

У групі пацієнтів із ЦД2 рівні СК і глобулінів у крові виявилися достовірно вищими, ніж у групі пацієнтів із ЦД1 (табл. 3). Вважають, що захворювання, обумовлені пуриновим дисметаболізмом (подагра, уратний літіаз тощо), схожі на ускладнення в хворих на ЦД2. На-

таблиця 2. Розподіл пацієнтів за типом цукрового діабету, статтю та наявністю артропатії, $M \pm m$, n (\%)

\begin{tabular}{llll}
\hline \multirow{2}{*}{ Група } & Стать & \multicolumn{2}{l}{ Артропатія } \\
\cline { 3 - 4 } & & відсутня & наявна \\
\hline ЦД1 & чоловіки & $5(35,7 \pm 12,8)$ & $9(64,3 \pm 12,8)$ \\
$\left(\chi^{2}=0,0002 ;\right.$ & жінки & $11(35,5 \pm 8,6)$ & $20(64,5 \pm 8,6)$ \\
$p=0,988)$ & загалом & $16(35,6 \pm 7,1)$ & $29(64,4 \pm 7,1)$ \\
ЦД2 & чоловіки & $4(21,1 \pm 9,4)$ & $15(79,0 \pm 9,3)$ \\
$\chi^{2}=0,02 ;$ & жінки & $8(19,5 \pm 6,2)$ & $33(80,5 \pm 6,2)$ \\
$p=0,889)$ & загалом & $12(20,0 \pm 5,2)$ & $48(80,0 \pm 5,2)$ \\
Обидві групи & чоловіки & $9(27,3 \pm 7,8)$ & $24(72,7 \pm 7,8)$ \\
$\left(\chi^{2}=0,01 ;\right.$ & жінки & $19(26,4 \pm 5,2)$ & $53(73,6 \pm 5,2)$ \\
$p=0,924)$ & загалом & $28(26,7 \pm 4,3)$ & $77(73,3 \pm 4,3)$ \\
\hline
\end{tabular}


разі гіперурикемію визнано одним із найважливіших компонентів метаболічних розладів, iï розглядають як ймовірний предиктор Цд2, а також як один із чинників патогенезу ендотеліальної дисфункції та гіперактивації симпато-адреналової системи. Мікрокристали СК ініціюють синдром системної запальної відповіді, діючи як ендогенний флогоген - ініціатор запалення. СК у формі іонів, що захоплюють активні форми кисню, задіяно в формуванні синдрому компенсаторного протизапального захисту, що провокує гіперпродукцію СК за ЦД [18]. Дослідження останніх років показали, що саме у хворих на ЦД2 гіперурикемія може бути діагностичним критерієм ураження суглобів [19]. Є дослідження, які доводять, що остеоартричний процес у суглобі може провокувати локальну кристалізацію уратів, надто в умовах гіперглікемії. У свою чергу мікрокристали уратів призводять до механічного ураження суглоба - виникнення запалення та прогресування остеоартриту [20].

Також у групі пацієнтів із ЦД2 виявлено вищий рівень ревматоїдного чинника та C-реактивного білка (з позитивною пробою). За іншими лабораторними показниками, у т.ч. антистрептолізином, статистичних відмінностей не виявлено. Ревматоїдний чинник (автоантитіла IgM, а також IgA та IgG класів, які реагують із Fc-фрагментом IgG) є стандартним імунологічним маркером захворювання суглобів. Ревматоїдним чинником (РЧ) називають сукупність аномальних антитіл (імуноглобулінів), які виробляються клітинами внутрішньосуглобової оболонки та синовіальної рідини суглобів. Отже, хворі на ЦД2 мають більш виражені запальні зміни, у тому числі синовіїти, які призводять до підвищення даного показника. За фізико-хімічними властивостями та специфічними особливостями пентамеру його можна вважати вектором, який здатен активувати функції всіх клітин сполучної тканини та безпосередньо здійснювати біологічну функцію запалення [21].

Синтез С-реактивного білка запускається та контролюється низкою відповідних медіаторів, насамперед цитокінів. Кожен із цитокінів виконує свою функцію, унікальну та незалежну. Відомо, що цитокіни - це первинні активатори певних генів, які починають діяти в умовах запалення, у тому числі суглобів.
Таблиця 3. Статистичні характеристики середніх клініколабораторних показників у групах обстежених (t-test)

\begin{tabular}{|c|c|c|c|c|c|c|c|c|}
\hline \multirow[t]{2}{*}{ Показник } & \multicolumn{3}{|l|}{ цд1 } & \multicolumn{3}{|l|}{ цд2 } & \multirow[t]{2}{*}{$t$} & \multirow[t]{2}{*}{$p$} \\
\hline & $M$ & $\mathrm{~m}$ & $\sigma$ & $M$ & $\mathrm{~m}$ & $\sigma$ & & \\
\hline $\mathrm{HbA1c} \%$ & 7,99 & 0,15 & 1,01 & 8,04 & 0,13 & 1,02 & 0,28 &, 780 \\
\hline $\begin{array}{l}\text { Білірубін } \\
\text { загальний, } \\
\text { мкмоль/л }\end{array}$ & 10,86 & 1,31 & 3,92 & 10,10 & 1,04 & 4,87 & 0,41 & ,683 \\
\hline $\begin{array}{l}\text { Білірубін } \\
\text { прямий, } \\
\text { мкмоль/л }\end{array}$ & 3,32 & 0,57 & 1,61 & 3,09 & 0,46 & 2,16 & 0,28 & 0,785 \\
\hline $\begin{array}{l}\text { Білірубін } \\
\text { непрямий, } \\
\text { мкмоль/л }\end{array}$ & 8,35 & 0,75 & 2,11 & 7,00 & 0,73 & 3,41 & 1,04 & 0,30 \\
\hline $\begin{array}{l}\text { Аланінамі- } \\
\text { нотрансфе- } \\
\text { раза, ОД/л }\end{array}$ & 20,80 & 3,92 & 13,01 & 28,70 & 3,56 & 17,46 & 1,33 & 0,19 \\
\hline $\begin{array}{l}\text { Аспартат- } \\
\text { амінотранс- } \\
\text { фераза, } \\
\text { ОД/л }\end{array}$ & 19,22 & 1,48 & 4,90 & 25,59 & 3,37 & 16,51 & 1,25 & 0,22 \\
\hline $\begin{array}{l}\text { Лужна } \\
\text { фосфатаза, } \\
\text { ОД/л }\end{array}$ & 91,11 & 19,80 & 59,40 & 66,72 & 3,62 & 17,34 & 1,82 & 0,07 \\
\hline $\begin{array}{l}\text { Гамма-глу- } \\
\text { тамінтранс- } \\
\text { фераза, } \\
\text { ОД/л }\end{array}$ & 41,55 & 14,84 & 41,96 & 35,81 & 4,52 & 21,67 & 0,50 & 0,62 \\
\hline $\begin{array}{l}\text { Креатинін, } \\
\text { мкмоль/л }\end{array}$ & 90,00 & 32,08 & 55,57 & 84,20 & 17,37 & 49,12 & 0,17 & 0,86 \\
\hline $\begin{array}{l}\text { Сечовина, } \\
\text { ммоль/л }\end{array}$ & 10,65 & 6,43 & 11,13 & 7,08 & 1,39 & 3,68 & 0,80 & 0,44 \\
\hline СК, ммоль/л & & 14,11 & 93,58 & 336,62 & 13,06 & 101,14 & 4,38 & 0,001 \\
\hline $\begin{array}{l}\text { Загальний } \\
\text { білок, г/л }\end{array}$ & 70,03 & 1,09 & 5,68 & 68,91 & 0,84 & 4,97 & 0,83 & 0,411 \\
\hline $\begin{array}{l}\text { Альбуміни, } \\
\text { г/л }\end{array}$ & 56,78 & 2,89 & 12,60 & 56,27 & 1,60 & 5,98 & 0,14 & 0,89 \\
\hline $\begin{array}{l}\text { Глобуліни, } \\
\text { г/л }\end{array}$ & 39,76 & 1,14 & 4,98 & 43,73 & 1,60 & 5,98 & 2,08 & 0,04 \\
\hline $\begin{array}{l}\text { Коефіцієнт } \\
\text { альбуміни/ } \\
\text { глобуліни }\end{array}$ & 1,55 & 0,08 & 0,37 & 1,32 & 0,09 & 0,32 & 1,84 & 0,07 \\
\hline $\begin{array}{l}\text { Антистреп- } \\
\text { толізин, } \\
\text { ОД/мл }\end{array}$ & 196,90 & 57,39 & 151,85 & 113,21 & 34,74 & 104,21 & 1,31 & 0,212 \\
\hline РЧ, мОД/мл & 9,04 & 0,70 & 2,23 & 11,24 & 0,74 & 3,04 & 1,98 & 0,058 \\
\hline СОБ, мг/л & 5,03 & 1,90 & 7,85 & 14,96 & 3,55 & 20,09 & 1,95 & 0,05 \\
\hline
\end{tabular}

Активовані цитокіни (IL-1, TNF- $\alpha$, IL-6 та інтерферони), є активаторами імунного запалення, яке врешті решт призводить до остеоартритів [12]. У випадках запалення, інфекції або іншого ушкодження C-реактивний білок (СРБ) синтезується гепатоцитами під дією цитокінів «першого покоління» - IL-1, IL-6, які мають прозапальні властивості та здат- 
ні активувати систему нуклеарного чинника транскрипції - NF-kb.

Також за допомогою дисперсійного аналізу проаналізовано можливий вплив типу діабету на ревматологічні показники. За результатами вивчення ізольованого впливу типу ЦД встановлено, що саме ЦД2 справляє достовірний вплив на варіативність показників РЧ, СРБ, СК, глобулінів і складає відповідно $13,6 \pm 3,5 \%$ $(\mathrm{p}<0,05), 7,5 \pm 1,9 \%(\mathrm{p}<0,05), 15,8 \pm 0,8 \%(\mathrm{p}<0,01)$ i 12,2 $\pm 2,8 \%(\mathrm{p}<0,05)$ їх загальної дисперсії.

Для виявлення можливого зв'язку показників ревматоїдного профілю та артропатії побудовано таблиці спряженості для таких показників, як антистрептолізин, РЧ і СРБ. Оскільки сума спостережень у деяких підгрупах була меншою від п'яти, рівень достовірності в таблицях $2 \times 2$ оцінювали 3 поправкою Йейтса. Не виявлено достовірного зв'язку між наявністю/відсутністю артропатії та градаціями показників антистрептолізин і РЧ $(\mathrm{p}>0,1)$, що, можливо, обумовлено малим розміром вибірки для даних пропорцій.

Результати, отримані в дослідженні розподілу пацієнтів за градаціями СРБ та артропатій мали достатню потужність статистичного дослідження для групи пацієнтів із ЦД2

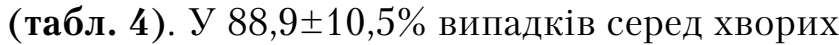
без артропатії тест на СРБ дав негативний результат, тоді як у $80,0 \pm 6,3 \%$ випадків серед хворих з артропатіями тест був позитивним.

Детальніший аналіз дозволив визначити, що частка хворих із позитивним тестом на СРБ зростає з прогресуванням артропатії $(\mathrm{r}=0,51 ; \mathrm{p}<0,001)$ (рис. 1). Так, для 1-ї стадії артропатії реакція на СРБ була позитивною в $66,7 \pm 27,2 \%$ випадків, для $2-і ̈-$ у $76,9 \pm 8,3 \%$,

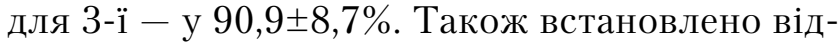
мінності між частками пацієнтів із позитив-

таблиця 4. Розподіл пацієнтів із цукровим діабетом за градаціями С-реактивного білка та наявністю/відсутністю артропатії, $\mathrm{P} \pm \mathrm{m}, \mathrm{n}(\%)$

\begin{tabular}{llll}
\hline \multirow{2}{*}{ група } & \multirow{2}{*}{ Артропатія } & \multicolumn{2}{l}{ С-реактивний білок } \\
\cline { 3 - 4 } & & негативний & позитивний \\
\hline ЦД1 & відсутня & $8(61,5 \pm 13,5)$ & $5(38,5 \pm 13,5)$ \\
$\left(\chi^{2}=0,05 ;\right.$ & наявна & $13(52,0 \pm 10,0)$ & 12 \\
$p=0,828)$ & & & $(48,0 \pm 10,0)$ \\
& обидві групи & $21(55,3 \pm 8,1)$ & $17(44,7 \pm 8,1)$ \\
ЦД2 & відсутня & $8(88,9 \pm 10,5)$ & $1(11,1 \pm 10,5)$ \\
$\left(\chi^{2}=12,9 ;\right.$ & наявна & $8(20,0 \pm 6,3)$ & $32(80,0 \pm 6,3)$ \\
$p=0,001)$ & обидві групи & $16(32,7 \pm 6,7)$ & $33(67,4 \pm 6,7)$ \\
\hline
\end{tabular}

ним СРБ і відсутністю артропатії $(11,1 \pm 10,5 \%)$ та наявністю артропатії 2-ї $(\mathrm{t}=4,7 ; \mathrm{p}<0,001)$ i 3-ї $(\mathrm{t}=5,6 ; \mathrm{p}<0,001)$ стадій. Частки пацієнтів із відсутністю артропатії та за наявності артропатії 1-ї стадії статистично не різнилися $(\mathrm{t}=1,6 ; \mathrm{p}>0,1)$.

Статистичного підтвердження зростання кількісних показників ревматоїдного профілю зі збільшенням стадії артропатії не виявлено.

Встановлено підвищення середнього рівня СК зі збільшенням стадії артропатії як у групі пацієнтів із ЦД1 ( $F=4,4 ; p=0,009)$, так і в групі з ЦД2 ( $\mathrm{F}=17,9 ; \mathrm{p}<0,001)$ (рис. 2).

У хворих на ЦД1 виявлено достовірні відмінності середнього рівня СК залежно від наявності/відсутності артропатії ( $\mathrm{t}=2,8 ; \mathrm{p}=0,008)$. Між пацієнтами з відсутністю артропатії та артропатією 1-ї стадії ( $\mathrm{t}=0,97 ; \mathrm{p}=0,342), 1$-ї та 2-ї стадій $(\mathrm{t}=1,7 ; \mathrm{p}=0,110)$, а також 2-ї та 3 -ї стадій $(\mathrm{t}=1,4 ; \mathrm{p}=0,477)$ достовірних відмінностей середніх значень СК не виявлено, проте знайде-

цд 2 типу $(\mathrm{N}=49)$

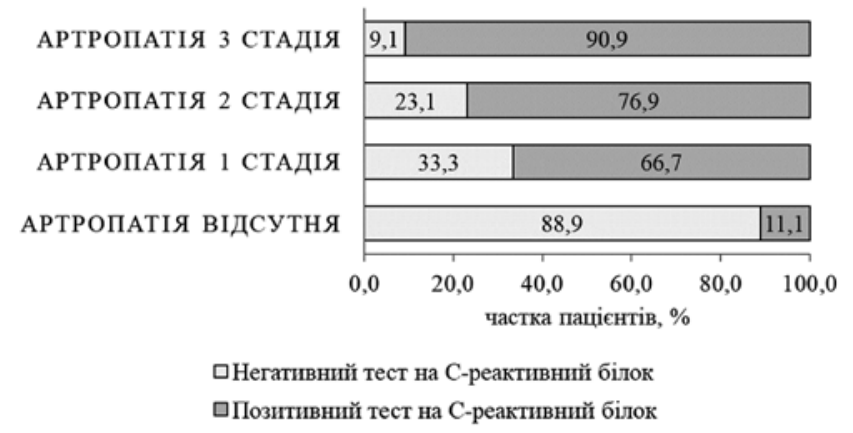

Рис. 1. Розподіл хворих із цукровим діабетом 2-го типу за результатами тесту на С-реактивний білок і стадіями артропатії (\%).

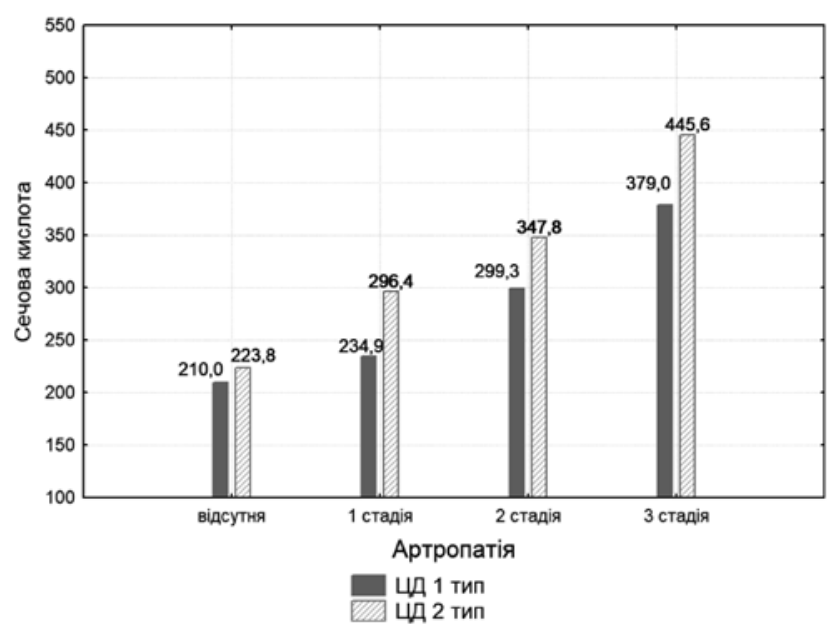

Рис. 2. Розподіл середнього рівня сечової кислоти за типом цукрового діабету та стадією артропатії. 
но відмінності між пацієнтами з артропатією 1-ї та 3-ї стадій $(\mathrm{t}=2,3 ; \mathrm{p}=0,039)$.

За ЦД2 також виявлено достовірні відмінності середнього рівня СК залежно від наявності/відсутності артропатії (t=5,2; $<00,001)$. Середні значення СК за відсутності артропатії та у хворих з артропатією 1-ї стадії статистично не різнилися $(t=1,7 ; p=0,107)$. Відмінності виявлено між показниками пацієнтів з артропатією 1-ї та 2-ї стадій $(\mathrm{t}=2,2 ; \mathrm{p}=0,038)$, а також 2-ї та 3-ї стадій ( $\mathrm{t}=11,1 ; \mathrm{p}=0,023)$.

Якщо тип діабету справляв вплив на дисперсію показника «СК» $-15,8 \pm 0,8 \%$ за його ізольованої дії $(\mathrm{p}<0,01)$, то стадії артропатії за ЦД1 справляли влив у 24,8 $\pm 2,7 \%(\mathrm{p}<0,01)$, а за ЦД2 вдвічі більший $-49,0 \pm 2,7 \%(\mathrm{p}<0,01)$.

Встановлено достовірний прямий кореляційний зв’язок показників «СК» та «артропатія» у загальній групі дослідження $(\mathrm{r}=0,45$; $\mathrm{p}<0,001)$ та в групі із ЦД2 $(\mathrm{r}=0,43 ; \mathrm{p}=0,001)$.

Отже, за отриманими результатами встановлено вірогідне підвищення показників, які характеризують ревматичні захворювання, у хворих на ЦД1 і ЦД2 з ураженнями суглобів. Для загальної групи дослідження виявлено прямий кореляційний зв'язок стадій артропатії із чинниками «антистрептолізин» $(\mathrm{r}=0,33$; $\mathrm{p}<0,01), \ll \mathrm{PU} \gg(\mathrm{r}=0,26 ; \mathrm{p}<0,05) \mathrm{i} \ll \mathrm{CP} \gg(\mathrm{r}=0,43 ;$ $\mathrm{p}<0,001)$. Подальше накопичення інформації та вивчення впливу показників ревматоїдного профілю в пацієнтів із ЦД на діагностику артропатій видається доцільним. Особливої уваги вимагає вивчення зв'язку СРБ та артропатій у пацієнтів із Цд2 з огляду на достовірне зростання позитивних тестів на СРБ (r=0,51; $\mathrm{p}<0,001)$ із підвищенням стадії артропатії, навіть на малих вибірках. На перспективність дослідження також вказують достовірно вищі показники РЧ і СРБ саме в пацієнтів із ЦД2, а також вплив чинника «тип ЦД» (7,5-13,6\%; $\mathrm{p}<0,05)$ на загальну дисперсію показників РЧ і СРБ. На більш виражені порушення обміну речовин у пацієнтів із ЦД2 та артропатіями вказує вдвічі вищий ізольований вплив чинника «артропатія» та прямий зв'язок градацій показника «СК» зі стадіями артропатії $(\mathrm{r}=0,43$; $\mathrm{p}=0,001)$, що також може мати діагностичне значення. Саме підвищення рівня СК у сироватці крові хворих на ЦД2 з артропатіями є найбільш чутливим діагностичним маркером ураження суглобів.
Але виключити вплив чинника «супутня патологія», який може обумовлювати виявлені відмінності в пацієнтів старшого віку, на підставі цього статистичного аналізу не можна, адже супутні діагнози не було враховано. Чинник «вік» на якісних даних і малій вибірці врахувати також практично неможливо.

\section{Висновок}

Отримані результати продемонстрували, що як найбільш чутливі діагностичні критерії у хворих із діабет-асоційованими остеоартритами можна рекомендувати використовувати рівень сечової кислоти в крові, ревматоїдного чинника та C-реактивного білка.

\section{Список використаної літератури}

1. Кондратьева ЛВ, Панафидина ТА, Герасимова ЕВ, Горбунова ЮН, Попкова ТВ, Насонов ЕЛ. Сахарный диабет и гипергликемия у больных ревматоидным артритом. Современная ревматология. 2014;8(3):23-27. (Kondratyeva LV, Panafidina TA, Gerasimova EV, Gorbunova YN, Popkova TV, Nasonov EL. Diabetes mellitus and hyperglycemia in patients with rheumatoid arthritis. Modern Rheumatology Journal. 2014;8(3):23-27) (In Russ.) doi.org/10.14412/1996-7012-2014-3-23-27

2. Dong Q, Degree B, Liu H, Yang D, Zhang Y. Diabetes mellitus and arthritis: is it a risk factor or comorbidity? A systematic review and meta-analysis Medicine (Baltimore). 2017 May; 96(18): e6627 doi: 1097/MD.0000000000006627

3. Gabriel SE, Crowson CS, O'Fallon WM. Comorbidity in arthritis. J Rheumatol. 1999; 26:2475-9.

4. Shikhman AR, Brinson DC, Valbracht J, Lotz MK. Cytokine regulation of facilitated glucose transport in human articular chondrocytes. J. Immunol 2001; 167:7001-7008

5. Williams MF, London DA, Husni EM, Navaneethan S, Kashyap SR Type 2 diabetes and osteoarthritis: a systematic review and meta-analysis. Journal of Diabetes and its Complications. 2016;30(5):944-950

6. Su CC, Chen I, Young FN, Lian I. Risk of diabetes in patients with rheumatoid arthritis: a 12-year retrospective cohort study. J Rheumatol.2013; 40: 1513-1518

7. Dessein PH, Joffe BI, Stanwix AE, Christian B., Veller M Glucocorticoids and insulin sensitivity in rheumatoid arthritis. J Rheumatol. 2004; 31: 867-874.

8. Schett G, Kleyer A, Perricone C, Sahinbegovic E, Iagnocco A, Zwerina J. Diabetes is an independent predictor for severe osteoarthritis: results from a longitudinal cohort study Diabetes Care. 2013 Feb; 36(2): 403-409. doi: 10.2337/dc12-0924

9. Solomon DH, Love TJ, Canning C, Schneeweiss S. Risk of diabetes among patients with rheumatoid arthritis, psoriatic arthritis and psoriasis. Ann Rheum Dis. 2010; 69: 2114-2117.

10. Rehling T, Bjorkman A, Andersen M, Ekholm O, Molsted S. Diabetes Is Associated with Musculoskeletal Pain, Osteoarthritis, Osteoporosis, and Rheumatoid Arthritis Journal of Diabetes Research. 2019 Article ID6324348 doi.org/10.1155/2019/6324348

11. Louati K, Vidal C, Berenbaum F, Sellam J. Association between diabetes mellitus and osteoarthritis: systematic literature review and meta-analysis,» R.M.D. Open.2015;1(1): p. e000077

12. Ширинский ИВ, Калиновская НЮ, Ширинский ВС. Клинико-иммунологическая характеристика диабет-ассоциированного остеоартрита Медицинская иммунология. 2015;17: 8792. (Shirinsky IV, Kalinovskaya NYu, Shirinsky VS. Clinical and immunological characteristics of diabetes-associated osteoarthritis. Meditsinskaya Immunologiya 2015;17: 87-92.) (In Russ.) 
Оригінальні дослідження

13. Berenbaum F. Diabetes-induced osteoarthritis: from a new paradigm to a new phenotype. Ann. Rheum. Dis. 2011; 70:1354-6. doi:10.1136/ard.2010.146399 19.

14. Rosa SC, Rufino AT, Judas F, Tenreiro C, Lopes MC, Mendes AF. Expression and function of the insulin receptor in normal and osteoarthritic human chondrocytes: modulation of anabolic gene expression, glucose transport and GLUT-1 content by insulin. Osteoarthritis and Cartilage 2011; 19:719-27. 10.1016/j. joca.2011.02.004.

15. Lu M, Yan S, Yin W. Risk of Rheumatoid Arthritis in Patients with Type 2 Diabetes: A Nationwide Population-Based Case-Control Study PLoS One. 2014; 9(7): e101528. doi: 10.1371/journal. pone. 0101528 .

16. Ruscitti P, Ursini F, Cipriani P, Ciccia F, Liakouli V, Carubbi F. Prevalence of type 2 diabetes and impaired fasting glucose in patients affected by rheumatoid arthritis.Results from a cross-sectional study Medicine (Baltimore). 2017 Aug; 96(34): e7896. doi: 10.1097/MD.0000000000007896.

17. Magnusson K, Hagen KB, Osteras N, Nordsletten L, Natvig B, Haugen IK. Diabetes is associated with increased hand pain in erosive hand osteoarthritis - data from a population-based study. Arthritis Care Res (Hoboken) 2015; 67:187-95. doi:10.1002/ acr. 22460

18. Waine H, Nevinny D, Rosenthal J, Joffe IB. Association of osteoarthritis and diabetes mellitus. Tufts Folia Med. 1961; 7:13-9.

19. Orlenko V, Synytsa Y. Influence of asymptomatic hyperuricemia on the development of artropathy in patients with diabetes. The progressive researches «Science \&Genesis» 2015;1:37-42.

20. Xiao L, Lin S, Zhan F. The association between serum uric acid level and changes of MRI findings in knee osteoarthritis: A retrospective study. Medicine (Baltimore). 2019; 98(21): e15819 ID: mdl-31124983.

21. Lebiedz-Odrobina D, Kay J. Rheumatic manifestations of diabetes mellitus. Rheum. Diseases Clinics of North America. 2010; 36 (4):681-699.

(Надійшла до редакції 03.02.2020р.)

\section{Некоторые ревматологические показатели у больных с диабет-ассоциированными остеоартритами}

\section{В.Л. Орленко', К.Н. Тронько', Е.Т. Елизарова²}

'ГУ «Институт эндокринологии и обмена веществ им. В.П. Комиссаренко НАМН Украины»

2ГУ «Институт общественного здоровья им. О.М. Марзеева НАМНУ»

Резюме. На современном этапе актуальной является проблема ассоциации распространенных ревматических заболеваний, таких как ревматоидный артрит, остеоартроз и остеопороз, с сахарным диабетом (СД). К настоящему времени нет единого взгляда на роль биохимических и иммунных факторов, которые вызывают поражения суставов в условиях коморбидности. Целью данного исследования была оценка биохимических ревматологических показателей у больных СД1 и СД2 с диабет-ассоциированным остеоартритом. Материал и методы. В исследовании приняли участие 105 пациентов, которых распределили на группы по типу диабета, наличию и степени тяжести диабетической артропатии Пациентам проводили диагностику артропатий с помощью Узи суставов, ревмапробы определяли имунотурбодиметрическим методом. Результаты. В группе пациентов с СД1 артропатию об- наружено в 64,4\% случаев, в группе пациентов с СД2 - в 80,0\% $(t=1,8 ; p=0,07)$. У больных с артропатией выявлена прямая корреляционная связь стадий артропатии с факторами «антистрептолизин» $(r=0,33 ; p<0,01)$, «ревматоидный фактор» $(r=0,26 ; p<0,05)$ и «С-реактивный белок» $(r=0,43 ; p<0,001)$. Установлено повышение среднего уровня мочевой кислоты с увеличением стадии артропатии как в группе пациентов с СД1 ( $F=4,4 ; p=0,009)$, так и в группе с СД2 ( $F=17,9 ; p<0,001)$. Вывод. Исходя из полученных данных, можно рекомендовать использовать как наиболее чувствительные диагностические критерии у больных с диабет-ассоциированными остеоартритами уровень мочевой кислоты в крови, ревматоидного фактора и С-реактивного белка.

Ключевые слова: сахарный диабет, диабет-ассоциированный остеоартрит, ревматологические показатели, мочевая кислота.

\section{Some rheumatological indicators in patients with diabetes associated osteoarthritis}

\section{V.L. Orlenko', K.M. Tronko' ${ }^{1}$, O.T. Yelizarova ${ }^{2}$}

${ }^{1} \mathrm{SI}$ «V.P. Komisarenko Institute of Endocrinology and Metabolism NAMS of Ukraine», Kyiv, Ukraine

${ }^{2} \mathrm{SI}$ «O.M. Marzelev Institute for Public Health NAMS of Ukraine», Kyiv, Ukraine

Abstract. At the present stage, the problem of the association of common rheumatic diseases, such as rheumatoid arthritis, osteoarthrosis and osteoporosis with diabetes mellitus, is relevant. To date, there is no single view on the role of biochemical and immunological factors that cause joint damage in conditions of comorbidity. The aim of thestudy was to evaluate the biochemical rheumatological parameters in patients with type 1 and type 2 diabetes with diabetes associated osteoarthritis. Material and methods. The study involved 105 patients who were divided into groups by type of diabetes, the presence and severity of diabetic arthropathy. Patients were diagnosed with arthropathy using ultrasound of the joints, rheumatic tests were determined by immunoturbodimetric method. Results. In the group of patients with type 1 diabetes, arthropathy was found in $64.4 \%$ of patients, in the group of patients with type 2 diabetes - in $80.0 \%(t=1.8 ; p=0.07)$. Patients with arthropathy revealed a direct correlation between the stages of arthropathy and the factors «antistreptolysin» $(r=0.33 ; p<0.01)$, «rheumatoid factor» $(r=0.26 ; p<0.05)$ and «C-reactive protein» $(r=0.43 ; p<0.001)$. An increase in the average level of uric acid with an increase in the stage of arthropathy was established both in the group of patients with type 1 diabetes ( $F=4.4 ; p=0.009)$ and in the group with type 2 diabetes $(F=17.9 ; \mathrm{p}<0.001)$. Conclusions. Based on the data obtained, it is recommended to use the level of uric acid in the blood, rheumatoid factor and C-reactive protein as the most sensitive diagnostic criteria in patients with diabetes associated osteoarthritis.

Keywords: diabetes mellitus, diabetes associated osteoarthritis, rheumatology, uric acid. 